\title{
REVIEW
}

\section{Polyomavirus nephropathy in native kidneys and renal allografts: an update on an escalating threat}

\author{
Volker Nickeleit ${ }^{1}$ and Michael J. Mihatsch ${ }^{2}$ \\ 1 Nephropathology Laboratory, Department of Pathology, The University of North Carolina at Chapel Hill, Chapel Hill, NC, USA \\ 2 Institute for Pathology, University Hospital, Basel, Switzerland
}

\section{Keywords}

BK virus, decoy cells, electron microscopy, histology, infection, outcome, transplantation, screening.

\section{Correspondence \\ V. Nickeleit MD, Nephropathology Laboratory, Department of Pathology, The University of North Carolina at Chapel Hill, Chapel Hill, NC 27599-7525, USA. Tel.: +1-919-966-2421; fax: +1-919-966-4542; e-mail: \\ volker_nickeleit@med.unc.edu}

Received: 2 February 2006

Revision requested: 21 February 2006

Accepted: 2 June 2006

doi:10.1111/j.1432-2277.2006.00360.x

\begin{abstract}
Summary
Polyomavirus nephropathy, also termed BK-virus nephropathy (BKN) after the main causative agent, the polyoma-BK-virus strain, is a significant complication after kidney transplantation. BKN is the most common viral infection that affects renal allografts with a prevalence of $1-9 \%$ on average $8-13$ months post surgery. It can also occur sporadically in native kidneys. Viral nephropathy is caused by the (re)activation of latent $\mathrm{BK}$ viruses that enter into a replicative cycle under sustained and intensive immunosuppression. Pure productive kidney infections with JC- and SV-40 polyomaviruses are exceptionally rare. $\mathrm{BKN}$ is morphologically defined by the presence of intranuclear viral inclusion bodies in epithelial cells and tubular injury, which is the morphological correlate for renal dysfunction. Renal disease can progress through different histologic stages (from early BKN stage A to late fibrotic stage $\mathrm{C}$ ) that carry prognostic significance; disease stages $\mathrm{B}$ and $\mathrm{C}$ often result in chronic kidney (allograft) dysfunction and end-stage renal disease. The clinical goal is to diagnose viral nephropathy in disease stage $\mathrm{A}$ and to limit chronic renal injury. Strategies to recognize, classify, and manage BKN are critically discussed including ancillary techniques for risk assessment and patient monitoring: (i) urine cytology and the search for so-called 'decoy cells'; (ii) PCR analyses for viral load measurements in the plasma and urine; and (iii) negative staining urine electron microscopy to identify viral particles.
\end{abstract}

\section{Introduction}

The polyomavirus family consists of different viral strains, among which the BK-, JC-, and the SV-40 strains are pathogenic in humans. Polyomaviruses are double stranded, nonencapsulated DNA viruses of approximately 5300 base pairs with substantial gene homology (approximately $70 \%$ between BK- and JC-viruses). They are tropic for certain cell types (BK- and JC-viruses for renal tubular and transitional cells) and require immune modulation and host cell activation for replication. This feature may help to explain compartment-specific disease processes, such as BK-virus-associated hemorrhagic cystitis after bladder injury in the setting of bone marrow transplantation (and not BK-virus nephropathy, BKN), versus BKN after kidney transplantation and tubular injury (and generally not hemorrhagic cystitis). Polyomaviruses adhere to their specific host cells through binding of viral capsid proteins (likely in the VP-1 region) to cell surface receptors; $\mathrm{BK}$-viruses likely bind to $\mathrm{N}$-linked glycoproteins containing $\alpha$ (2,3)-linked sialic acids/gangliosides GD1b and GT1b $[1,2]$. After cell entry via caveola-mediated endocytosis, the BK-viruses migrate through the cytoplasm/endoplasmatic reticulum/microtubules and the nuclear pores into the host cell nucleus, where viral transcription, replication, and assembly take place [2-5]. Ultimately, host cells are lysed and mature daughter virions released.

Polyomaviruses are ubiquitous and have specifically adapted to their hosts during evolution. They are of no clinical significance in immune competent individuals. It 
is important to remember that the viruses are often not cleared from the body after a primary infection, which occurs with 'flu-like symptoms' early in life. Rather, it is assumed that primary entry of BK- or JC-viruses (SV-40 viruses do not play a significant clinical role) into the host results in transient viremia and viral spread to permissive cells, in particular, transitional and renal tubular epithelial cells, where the viruses establish life-long latency under normal cellular and humoral immune-surveillance [6-9]. Latent polyomavirus infections cannot be identified histologically or immunohistochemically but rather require molecular techniques for detection (Southern blot or PCR analyses) $[6,8]$.

Disease caused by the re-activation of latent polyomaviruses is typically not seen in the immunecompetent host. Slight changes in the immune status (during pregnancy, in patients suffering from diabetes mellitus, or in 'healthy' individuals including stable renal allograft recipients) can, however, lead to transient, asymptomatic, and self-limiting viral activation [10], especially in the urothelium, which harbors latent BK-virus infections in $43 \%$ of individuals [11] (Table 1). Such activation is characterized by the detection of free viral particles in the urine (by electron microscopy or PCR techniques) and intranuclear viral inclusion bearing cells, so-called 'decoy cells' in urine cytology specimens. Polyomavirus (re)activation and the shedding of decoy cells are generally not associated with tissue injury and kidney dysfunction, i.e. a rise in serum creatinine levels, or other symptoms [12-14].

Disease caused by polyomaviruses is only seen in patients with pronounced and long-lasting immunosuppression (Table 1). Productive BK-virus infections and, in particular, BKN have gained considerable interest over the last decade. Our current knowledge of $\mathrm{BKN}$ is primarily based on findings made in humans. Thus far, only rare animal studies have been reported describing either incidental findings [15] or 'models of viral nephropathy' that unfortunately only vaguely resemble human disease [16-19].

\section{BK-virus nephropathy (BKN)}

BK-virus nephropathy affecting a kidney transplant was first described as a single case report by the pathologist Mackenzie in 1978 [20]. In subsequent years during the era of cyclosporine and azathioprine based immunosuppression, BKN was largely 'forgotten' [12,21]. The clinical scenario changed dramatically in the mid-1990s when new third generation immunosuppressive drugs, specifically, high-dose tacrolimus and mycophenolate-mofetil were introduced into the routine management of kidney transplant recipients worldwide [12,21-24]. Interestingly, one of the largest initial series of patients suffering from BKN was reported from the University of Pittsburgh, one of the first transplant centers that had largely replaced cyclosporine with tacrolimus [25]. Recently, Mengel et al. reported a 10-13 times higher odds ratio for $\mathrm{BKN}$ in patients under tacrolimus (trough level $>8 \mathrm{ng} / \mathrm{ml}$ ) and (high-dose) mycophenolate-mofetil therapy [26]; similar findings were reported by Rocha et al. [27]. Risk factors for BKN, however, are still only incompletely understood [6,27-33] and BKN has, on occasion, also been reported in centers still using conventional cyclosporine and azathoprine based therapy [34], or calcineurin inhibitor-free protocols containing sirolimus and mycophenolate-mofetil [35]. Currently, BKN is reported with a prevalence of $1-9 \%(6.5 \%$ at the University of North Carolina in Chapel Hill) in adult and pediatric patients; its incidence rate is rising [26-28,30,34,36-40]. BKN is by far the most important infectious complication affecting kidney transplants. It exceeds productive cytomegalovirus (CMV) infections of renal allografts by approximately 50-100

Table 1. Polyomavirus infections: terminology.

Primary infection

Latent infection

Serologic evidence of an infection

Viral activation

Viral disease (BKN, PML, hemorrhagic cystitis after BM-Tx)
Initial infection of host with polyomaviruses including viremic spread to permissive tissues; insignificant (often flu-like) clinical symptoms

Dormant asymptomatic infections of permissive cells (e.g. renal tubular, transitional cells) following the primary infection; virus detection only with molecular techniques

Varying antibody titer levels found in nearly all healthy children and $60-90 \%$ of asymptomatic adults; no correlation with latent intrarenal viral load levels; weak correlation with viral disease (BKN, PML)

Evidence of polyomavirus replication: (i) viral inclusion bearing 'decoy cells' or free virions in the urine; (ii) viral detection by PCR in the urine, serum or cerebrospinal fluid. Viral activation can be seen as a transient and asymptomatic event, or as part of viral disease

Histologic evidence of viral replication IN organs (cytopathic signs and/or positive immunohistochemistry or in situ hybridization signals) AND associated virally induced tissue injury (e.g. in kidneys*, brain, bladder*), often associated with clinical symptoms

BKN, polyoma-BK-virus nephropathy; PML, progressive multifocal leukoencephalopathy; BM-Tx, bone marrow transplantation.

*BKN pattern A shows only minimal acute tubular injury; signs of viral replication in transitional cells/the urothelium without mucosal injury in asymptomatic patients are not classified as disease. 
times. As effective antiviral treatment strategies are poorly defined, BKN often leads to severe allograft dysfunction and graft loss [12,21,28,36,37,39,41,42]. Graft failure rates, especially when BKN is diagnosed late or treatment strategies fail, can reach $50 \%$ to $>80 \%$ within 24 months $[26,43,44]$. Improved graft survival has recently been reported from centers with vigorous patient screening programs that facilitate an early diagnosis of $\mathrm{BKN}$ and early intervention $[28,29,31,45,46]$. In 2006, Wadei et al. from the Mayo Clinic reported very encouraging outcome data including a graft survival rate of $85 \%$ and chronic functional deterioration in only $38 \%$ of cases [47].

Polyomavirus nephropathy is nearly always caused by a productive infection with the BK strain. Only a minority of cases (approximately one third) show activation of polyoma-BK- and JC-viruses simultaneously with, as yet, undetermined biological significance $[48,49]$. Polyomavirus nephropathies that are only induced by a productive JC or SV40 virus infection are exceptionally rare [50,51]. $\mathrm{BKN}$ is practically never seen in association with a concurrent second viral infection of the kidney. We are only aware of two anecdotal cases, both of which showed dominant activation of either adenovirus [52] or CMV [53] with only focal 'minor' evidence of BKN. In severely immunocompromised transplant (other than kidney) and nontransplant patients, BK viruses can rarely also enter into a replicative cycle in the native kidneys [54-60]. We have seen two cases of $\mathrm{BKN}$ in native kidneys from patients suffering from B-cell lymphomas. Histologic changes induced by productive BK-, JC, or SV40-polyomavirus infections in renal allografts or native kidneys are identical; ancillary techniques such as immunohistochemistry, in situ hybridization, or PCR are required for the identification of viral strains.

BK-virus nephropathy has been diagnosed as early as 6 days and as late as 6 years postgrafting (mean: 380 days) $[28,34]$. The exceptional case observed at day 6 postsurgery by Sachdeva, M.S. and colleagues [34] showed high intrarenal BK-virus loads $\left(>2.5 \times 10^{5} \mathrm{BK}\right.$ copies per 25000 cell equivalents) typical for BKN (Nickeleit, V., pers. obs.). Depending on the extent of virally induced tubular injury, patients clinically present with varying degrees of allograft dysfunction. Serum creatinine levels vary from normal (early BKN stage A) to markedly increased (late stages with marked injury, BKN stages B and C; Table 2) $[28,29,38,61]$. Systemic signs of an infection (fatigue, fever) are absent (with only one exception) [62]. BKN is typically limited to the transplant, and the failed native kidneys seem to be free of disease [63]. BKvirus associated hemorrhagic cystitis, often seen after bone marrow transplantation, is not a characteristic symptom found in the setting of BKN. Although early observations linked productive infections of $\mathrm{BK}$ viruses to the development of ureteral stenosis [64], a recent series could only detect BK viruses in $8 \%(2 / 25)$ of histologically analyzed necrotic ureters [65]. The pathophysiological

Table 2. Histologic patterns/stages of polyoma-BK-virus nephropathy*

Pattern/stage A (early changes)

Pattern/stage B (florid changes)

Stage $B 1$

Stage $B 2$

Stage $B 3$

Pattern/stage C (late sclerosing changes)
- Viral activation in cortex and/or medulla with intranuclear inclusion bodies AND/OR positive immunohistochemistry or in situ hybridization signals

- No or minimal tubular epithelial cell necrosis/lysis

- No denudation of tubular basement membranes

- No or minimal interstitial inflammation in foci with viral activation

- No or minimal tubular atrophy and interstitial fibrosis ( $\leq 10 \%)$

- Marked viral activation in cortex and/or medulla

- Marked virally induced tubular epithelial cell necrosis/lysis and associated denudation of tubular basement membranes

- Interstitial inflammation** (mild to marked)

- Interstitial fibrosis and tubular atrophy (minimal to moderate, $\leq 50 \%$ )

- $\leq 25 \%$ of biopsy cores involved

- $>26 \%$ and $<50 \%$ of biopsy cores involved

- $\geq 50 \%$ of biopsy cores involved (if interstitial fibrosis and tubular atrophy $>50 \%$ : stage C)

- Viral activation in cortex and medulla

- Interstitial fibrosis and tubular atrophy $>50 \%$ of biopsy cores***

- Tubular epithelial cell necrosis/lysis and basement membrane denudation (minimal to marked)

- Interstitial inflammation** (minimal to marked)

\footnotetext{
*Additional signs of BK-virus activation are always present: (i) Decoy cells in the urine; (ii) detection of BK-virus DNA or RNA in the plasma and urine; (iii) detection of free virions and three dimensional viral aggregates, "Haufen", in the urine by negative staining electron microscopy.

** Interstitial inflammation and tubulitis can in some cases mark concurrent tubulo-interstitial cellular rejection; rejection induced changes are not part of this scoring scheme.

$\star * *$ Interstitial fibrosis and tubular atrophy interpreted to be mostly secondary to protracted virally induced tubular injury.
} 
significance of the activation of $\mathrm{BK}$ viruses in necrotic ureteral walls is undetermined, i.e. secondary viral activation in areas of injury (role of an innocent by-stander) versus causative effect (role of a driver). Evidence of ureteral stenosis in the setting of BKN is uncommon. A definitive diagnosis of BK-virus-induced nephropathy requires a kidney biopsy, and the detection of characteristic histologic changes.

\section{Morphology of BKN}

Two morphologic features define BKN in renal allografts and native kidneys: (i) intranuclear viral inclusion bodies in epithelial cells and (ii) virally induced tubular epithelial cell injury and lysis. BK viruses use the proliferative 'machinery' of the host cells for replication [66], and the formation of intranuclear viral inclusion bodies in tubular epithelial cells and parietal glomerular epithelial cells is a hallmark of a productive infection $[21,22,25,28,29,41,61,67]$. Viral replication ultimately results in the lysis/necrosis of inclusion bearing cells and the denudation of tubular basement membranes. This virally induced type of (acute) tubular injury is a morphologic correlate for the clinically observed kidney dysfunction [12,21,28,29,41,61]. Despite marked epithelial damage, however, the tubular basement membranes usually remain intact. They can serve as the structural skeleton for subsequent tubular regeneration once the viral replication ceases. Very rarely, BKN is associated with marked tubular rupture and the formation of large, nonnecrotizing granulomas.

Cytopathic epithelial cell changes and acute virally induced tubular injury typically show a focal distribution pattern, often involving the medulla. Severely damaged tubules containing many inclusion bearing epithelial cells are characteristically located adjacent to normal ducts (Fig. 1). This observation may reflect the ascending route of viral spread within infected nephrons. Signs of a productive BK-virus infection can also be detected in the transitional cell layer lining the renal pelvis, the ureters and/or the urinary bladder [21]. Viral inclusion bodies in the urothelium, however, are not part of the histologic hallmarks defining $\mathrm{BKN}$ as they can also be seen in patients with hemorrhagic cystitis lacking renal tubular involvement or as incidental findings marking asymptomatic viral activation $[12,14,68,69]$.

In some patients, BKN is associated with focal granular immune deposits along tubular basement membranes (positive staining by immunofluorescence microscopy with various antibodies directed against immunoglobulins and complement factors); this finding is currently of undetermined clinical significance [70]. The complement degradation product $\mathrm{C} 4 \mathrm{~d}$, a marker for an antibody- mediated alloresponse, is not seen in typical cases of $\mathrm{BKN}$; therefore, its presence indicates BKN and concurrent acute rejection (see below) [28,61,71,72]. Viral replication is not associated with marked tubular expression of MHC-class II (HLA-DR) [41].

All cases of BKN characteristically show large numbers of polyomavirus inclusion bearing cells in the urine, i.e. so-called decoy cells. The detection of decoy cells serves as an important ancillary diagnostic tool during clinical risk assessment (see below) [12,13,22,28,31,41,61,73-75].

\section{Ancillary diagnostic techniques}

Although the histologic changes are characteristic for BKN, they are not pathognomonic as other viral infections caused by Herpes Simplex Virus, Adenovirus, or Cytomegalovirus must be considered in the differential diagnosis $[41,76,77]$. Diagnostic confirmation of BKN is generally achieved by immunohistochemistry (with antibodies directed against the T-antigen - associated with viral replication, or against VP capsid proteins - associated with mature viral particles), in situ hybridization and/or electron microscopy. These techniques are well suited to identify viral families and potentially viral strains if a productive viral infection is already suspected by light microscopy $[28,41,78]$. Their routine diagnostic use as generalized screening tools to 'hunt' for a productive polyomavirus infection, however, is neither helpful nor cost effective $[21,26]$. PCR techniques may also be utilized to demonstrate viral DNA or RNA in tissue samples and to confirm the diagnosis of BKN $[57,79,80]$. However, PCR results must be interpreted with caution. Only strong amplification signals of viral DNA (greater than 10 BKvirus copies per cell equivalent), in the setting of histologically or immunohistochemically demonstrable virally induced cytopathic changes, can be used to confirm the diagnosis of $\mathrm{BKN}$ and to distinguish clinically significant productive from clinically insignificant latent $\mathrm{BK}$-virus infections $[6-8,57,60,79,81]$. The detection of viral RNA in renal biopsy cores by PCR clearly indicates viral replication. RNA extraction and amplification methods, however, are challenging techniques, susceptible to error, and do not provide additional information exceeding the results obtained with standard immunohistochemistry (such as the detection of the SV40-T antigen) $[57,80]$.

\section{Histologic stages/patterns of BKN}

BK-virus nephropathy can present with different histologic patterns and progress through various stages $[15,21,28,29,32,41,61,73,82]$. Three stages/patterns have recently been defined $[32,61,67,73]$. They are listed here with slight modifications (Table 2). 

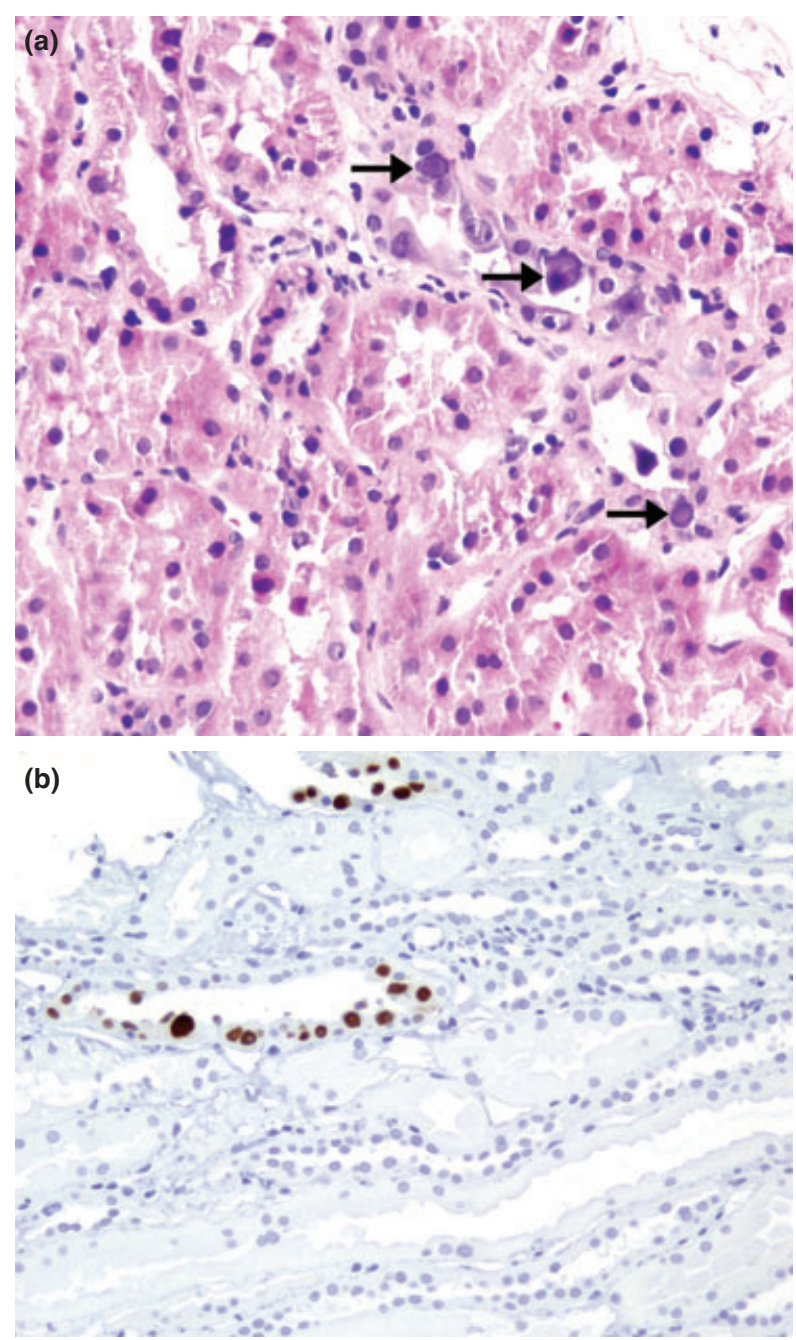

Figure 1a,b BK-virus nephropathy (pattern A; early stage). Only very few tubular epithelial cells show intranuclear viral inclusion bodies [arrows in (a)]; most cells are normal. The overall tubular and interstitial architecture is unaltered and virally induced tubular epithelial cell lysis and basement membrane denudation are lacking. (a) Hematoxylin and eosin (H\&E)-stained section, $\times 100$ original magnification. (b) Immunohistochemistry shows a characteristic nuclear staining reaction. Formalin fixed and paraffin-embedded tissue section, antibody directed against the SV-40 T antigen, $\times 100$ original magnification [same case as illustrated in (a)].

\section{Pattern A (limited/early stage)}

Signs of viral activation are found in cortical and/or medullary tubular cross-sections (Fig. 1a and b). Typical for pattern A is the lack of virally induced epithelial cell lysis. Denudation of tubular basement membranes is inconspicuous. Viral activation is characterized by intranuclear viral inclusion bodies that can be lacking on exceptionally rare occasions. In these latter cases, viral activation is only identified by positive intranuclear immunohistochemical or
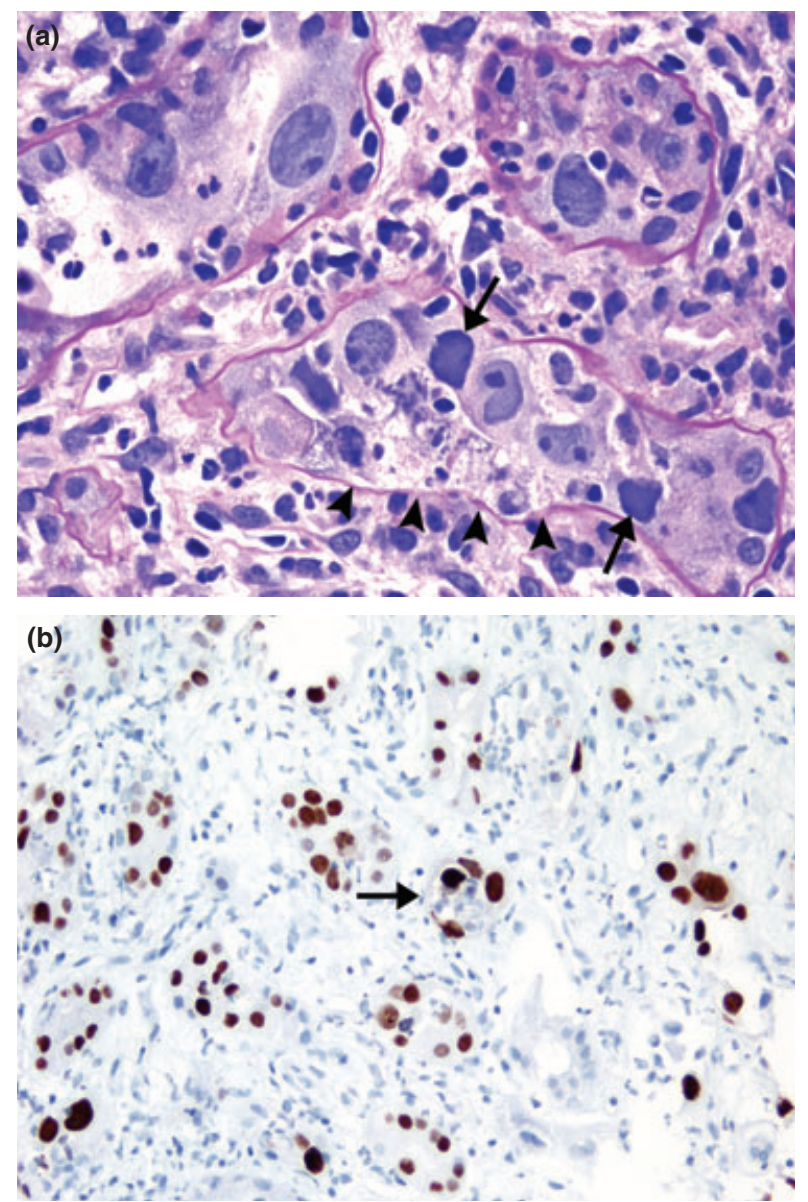

Figure 2a,b BK-virus nephropathy (pattern B; florid stage). Intranuclear viral inclusion bodies are seen within tubular epithelial cells [arrows in (a)]. There is virally induced epithelial cell lysis and denudation of the tubular basement membranes [arrowheads in (a)]. The interstitial compartment shows edema and marked inflammatory cell infiltrates, also involving tubules (tubulitis). (a) Periodic Acid Schiff (PAS) stained section, $\times 140$ original magnification. (b) Immunohistochemistry demonstrates widespread nuclear staining in most tubules. The arrow marks a tubular cross-section with virally induced denudation of the basement membrane. Formalin fixed and paraffin embedded tissue section, antibody directed against the SV-40 T antigen, $\times 100$ original magnification [same case as illustrated in (a)].

in situ hybridization signals (e.g. the detection of the SV40$\mathrm{T}$ antigen, which is an early marker of viral replication). Interstitial inflammation in pattern $\mathrm{A}$ is absent or minimal and limited to parenchymal foci showing signs of viral activation. Tubular atrophy and interstitial fibrosis do not involve more than $10 \%$ of the biopsy sample. Changes classified as pattern A are frequently very patchy in nature; they can be most pronounced in the renal medulla.

Pattern B (B1-B3, florid stage)

Signs of viral activation are found in cortical and medullary tubular cross-sections with conspicuous, virally 
induced epithelial cell lysis, denudation of tubular basement membranes, and interstitial edema (Fig. 2a and b). Mononuclear inflammatory cell infiltrates (sometimes containing abundant plasma cells and polymorphonuclear leukocytes) are common, and tubulitis can be observed in areas of viral activation. Interstitial fibrosis and tubular atrophy are minimal to moderate (involving, per definition, $<50 \%$ of the biopsy cores). Changes classified as pattern B may occur in the renal cortex and medulla and can be subclassified as follows: (i) pattern B1, $\leq 25 \%$ involvement of the biopsy cores; pattern B2, 26-49\% involvement of the biopsy cores; pattern B3, $\geq 50 \%$ involvement of the biopsy cores (virally induced tubular injury and/or inflammation; fibrosis and tubular atrophy are, per definition, less than 50\%).

\section{Pattern C (late, sclerosing stage)}

Signs of viral replication are associated with tubular epithelial cell injury (Fig. 3a and b). Interstitial inflammation can vary from minimal to marked. Fibrosis and tubular atrophy secondary to virally induced injury involve, per definition, more than $50 \%$ of the tissue sample. Changes classified as pattern $\mathrm{C}$ are frequently most pronounced in the renal cortex but can also be seen in the medulla.

Although the unequivocal classification of the different patterns of BKN may occasionally be challenging because of other concurrent diseases, such as pre-existing donor lesions with interstitial fibrosis or acute or chronic rejection, an attempt to classify BKN should be made as these patterns carry pathophysiological, clinical and prognostic significance.

Stage/pattern A represents the initial phase of BKN with only very focal 'nonlytic' viral activation. It is frequently found in the medulla and likely represents re-activated foci of latent BK-virus infections. Pattern A, in contrast to patterns $\mathrm{B}$ and $\mathrm{C}$, is diagnosed early ( 8.7 months posttransplantation versus 15.9 months respectively) [46] and often responds to therapy with favorable long-term graft function and survival $[28,31,38,41,45-47,61,73]$. Resolution of BKN has been observed in up to $78 \%$ of patients [46]. As tubular injury in pattern A is very limited, graft function typically remains stable, and the optimal timing of a diagnostic graft biopsy becomes a clinical challenge $[28,41,46,61]$. BKN pattern A can progress to patterns B or $\mathrm{C}$ if productive viral replication spreads and virally induced tubular injury persists over weeks to months (compare Fig. 1 with Fig. 3). In one series, progression was observed in repeat diagnostic biopsies in 37\% of patients initially presenting with pattern $\mathrm{A}$ and in $60 \%$ presenting with pattern $B$ [82]. Regression from pattern $B$ (in particular B1) to pattern A may be observed during
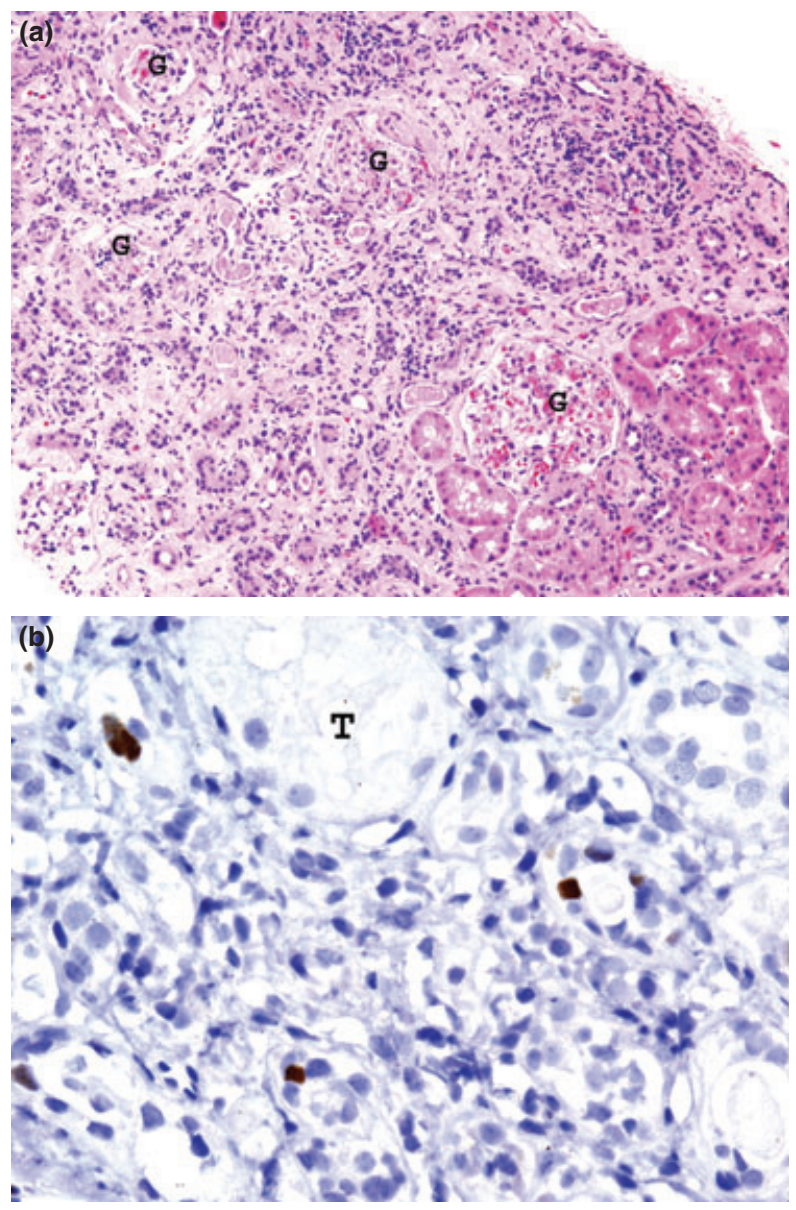

Figure 3a,b BK-virus nephropathy (pattern C; late, sclerosing stage). The late, sclerosing phase of BKN depicted by tubular atrophy and diffuse interstitial fibrosis; glomeruli $(\mathrm{G})$ are uninvolved. Only a small island of nonatrophic tubules is seen in the lower right hand corner. This is the same patient as illustrated in Fig. 1, fourteen weeks after the initial diagnosis. (a) Hematoxylin and eosin (H\&E) stained section, $\times 70$ original magnification. (b) Immunohistochemistry shows viral replication in rare nuclei located in atrophic tubules; (T) marks a nonatrophic tubular cross-section. Formalin fixed and paraffin embedded tissue section, antibody directed against the SV-40 T antigen, $\times 140$ original magnification [same case as illustrated in (a)].

the resolution of BKN; fibrosis and tubular atrophy found in pattern $\mathrm{C}$ are irreversible.

The therapeutic goals of $\mathrm{BKN}$ in patterns $\mathrm{A}$ and $\mathrm{B}$ are to limit viral replication and tubular injury, to promote tubular epithelial cell regeneration and to prevent disease progression to pattern $\mathrm{C}$ with irreversible scarring (Fig. 3). BKN-pattern C is typically associated with severe allograft dysfunction or loss $[21,29,61,82]$.

BK-virus nephropathy patterns A-C are associated with varying degrees of interstitial inflammation. The inflammatory cell infiltrate, especially in pattern B, can represent 'virally induced' interstitial nephritis with polymorphonu- 
clear leukocytes located adjacent to severely injured tubules (with urine back-leak), abundant plasma cells, mononuclear cells, and tubulitis in foci with viral activation $[15,21,28,41,61,67,73]$. Cytotoxic T lymphocytes seem to play a role in the containment of BK virus [83]. However, in some cases (especially in pattern A that should, per definition, lack significant inflammation), mononuclear cell infiltrates rich in lymphocytes and a lymphocytic tubulitis can be found representing BKN and concurrent acute allograft rejection [71]. The diagnosis of acute rejection and concurrent BKN is challenging. It carries clinical significance as therapeutic strategies should be adapted and rejection should be treated $[28,31,41,45,61,71]$. Rejection can be more easily diagnosed if transplant endarteritis, transplant glomerulitis, tubulitis in areas without viral activation, tubular expression of MHC-class II (HLA-DR) or C4d along peritubular capillaries are detected $[28,29,31,41,45,61,71,72]$. As cases of BKN with marked tubulitis generally fare poorly [73], unrecognized tubulointerstitial cellular rejection (Banff type I) may potentially contribute to $\mathrm{BKN}$-induced graft demise more frequently than commonly suspected $[71,84]$.

The immunohistochemical phenotyping of the inflammatory cells in BKN has shown plasma cell (CD138) as well as B- (CD20) or T-cell (CD3) dominant infiltrates with currently undetermined pathophysiological significance. It is not diagnostically helpful for distinguishing viral nephritis from concurrent acute cellular rejection [85-87].

\section{Patient management}

Although specific antiviral treatment strategies are still largely undefined $[32,88]$, much progress has been made to better assess the risk for $\mathrm{BKN}$, to optimize the timing of a diagnostic graft biopsy (patient screening), and to evaluate the response to therapy (patient monitoring). These strategies result in improved graft survival and also contribute to the reduction of health care costs $[28,31,32,41,45,67,89,90]$. Here, we critically review selected management recommendations rendered during the first interdisciplinary conference on polyomavirus-associated nephropathy [32].

The risk for BKN after kidney transplantation is classified as:

(a) level 0 - no risk;

(b) level 1 - possible BKN (low risk, additional testing and surveillance are required);

(c) level 2 - presumptive BKN (high risk, allograft biopsy and close surveillance are required);

(d) level 3 - definitive BKN (biopsy proven viral nephropathy).

The diagnosis of BKN (in renal transplants and native kidneys) must be made in a biopsy specimen, ideally containing two cores of cortex and medulla obtained with a 15-gauge needle (definitive BKN, level 3). As mentioned above, BKN often only focally affects renal tubules and collecting ducts. Thus, foci of productive viral replication may be missed because of sampling errors if: only one biopsy core is taken; the needle size is too small (e.g. 18 gauge); medullary parenchyma is not sampled. Biopsies from cases with BKN consisting of multiple tissue cores showed individual biopsy cylinders with discordant 'BKpositivity' in $37 \%$ of cases [73]. In our own biopsy material, $25 \%$ of cases showed cytopathic viral changes limited to the renal medulla. Thus, the diagnosis of BKN may be missed in $25-37 \%$ of biopsy samples only consisting of one small core of cortex.

In $\mathrm{BKN}$ pattern $\mathrm{A}$, renal function can be normal, thereby, obscuring the need for a diagnostic biopsy $[28,38,41]$. To adequately assess the risk for viral nephropathy and to optimize the timing for a biopsy, signs of viral activation can be used for clinical guidance (Table 1, Fig. 4): search of polyomavirus inclusion bearing decoy cells by urine cytology, assessment of free virions in the urine by negative staining electron microscopy, quantitative PCR analyses to measure BK-virus DNA loads in the urine or plasma, or alternatively, quantitative RNA measurements to detect viral RNA in the urine [12,13,21$23,28,29,31,41,61,73,74,82,89,91-94]$. As the latter technique is susceptible to technical errors, not in common use, and not superior to the widely available detection of decoy cells, it will not be considered further [74]. Signs of viral activation should be integrated into an individual patient risk profile.

\section{Decoy cells}

All patients with BKN shed abundant polyomavirus inclusion bearing 'decoy cells' in the urine. They can be easily detected in standard Papanicolaou-stained cytology preparations or - with some expertise - also in the urine sediment by phase contrast microscopy $[12,13,21,28,31$, $41,73,75,82,95-97]$. Polyomavirus inclusion bearing decoy cells are believed to commonly originate from the transitional cell layer and to often contain BK viruses $[13,14,68,69,98]$. Although one decoy cell is sufficient to mark the activation of polyomaviruses, in clinical practice an arbitrary threshold level of more than 10 decoy cells per liquid-based cytology preparation (i.e. ThinPrep) has been set to distinguish 'decoy positive' from 'decoy negative' patients [13]. The positive predictive value of a 'positive' decoy cell analysis to predict $\mathrm{BKN}$ is $25-30 \%$; however, the negative predictive value is greater than $99 \%$, i.e. 'negative decoy analysis', no viral nephropathy $[13,28,31,41,73,75]$. Any further quantification of decoy cells does not provide additional clinically relevant infor- 


\section{Patient screening period}

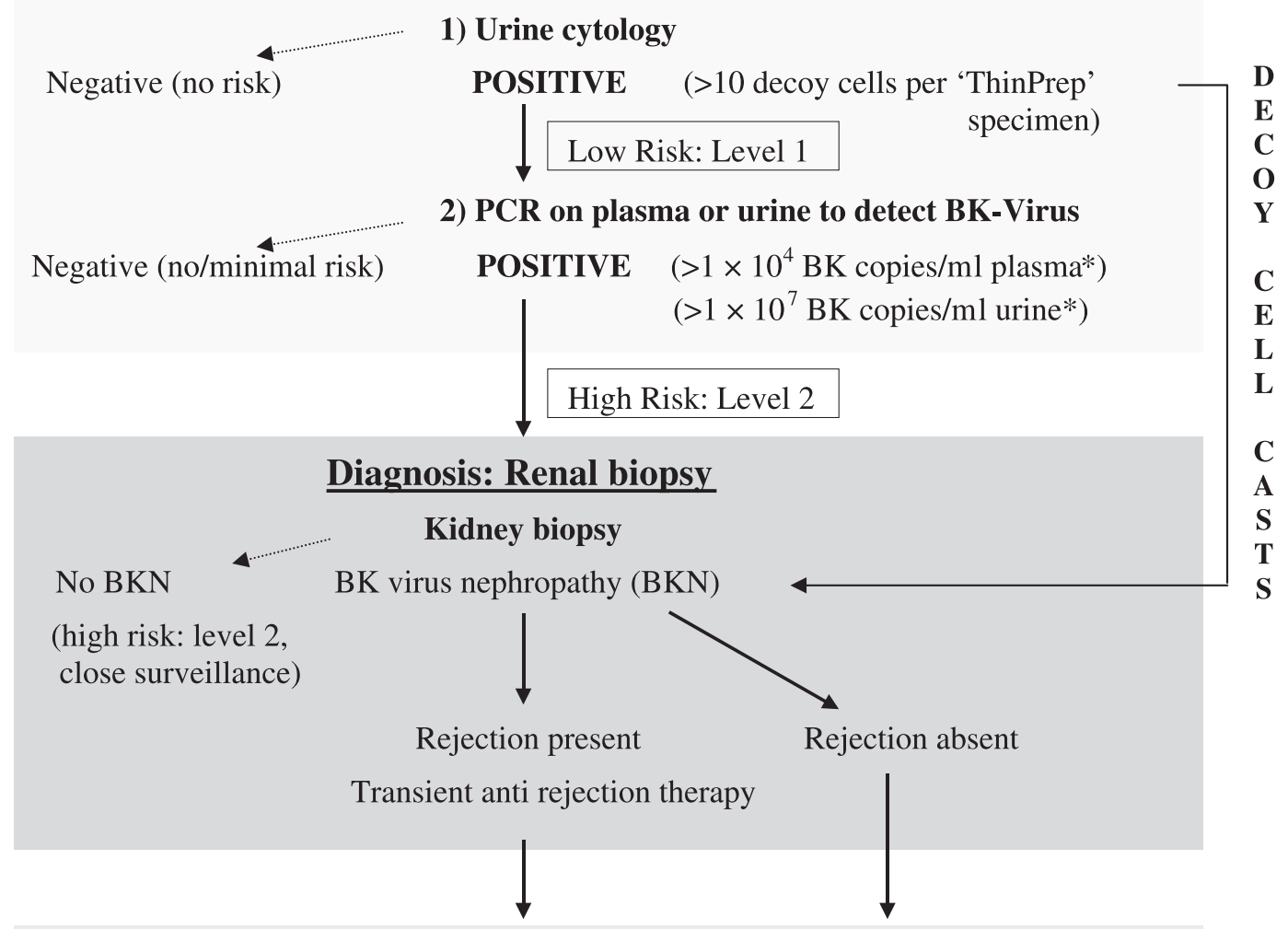

Persistent BKN - Patient treatment and monitoring period

Therapy attempts (for many weeks to months)

(e.g. low-dose immunosuppression, cidofovir, leflunomide)

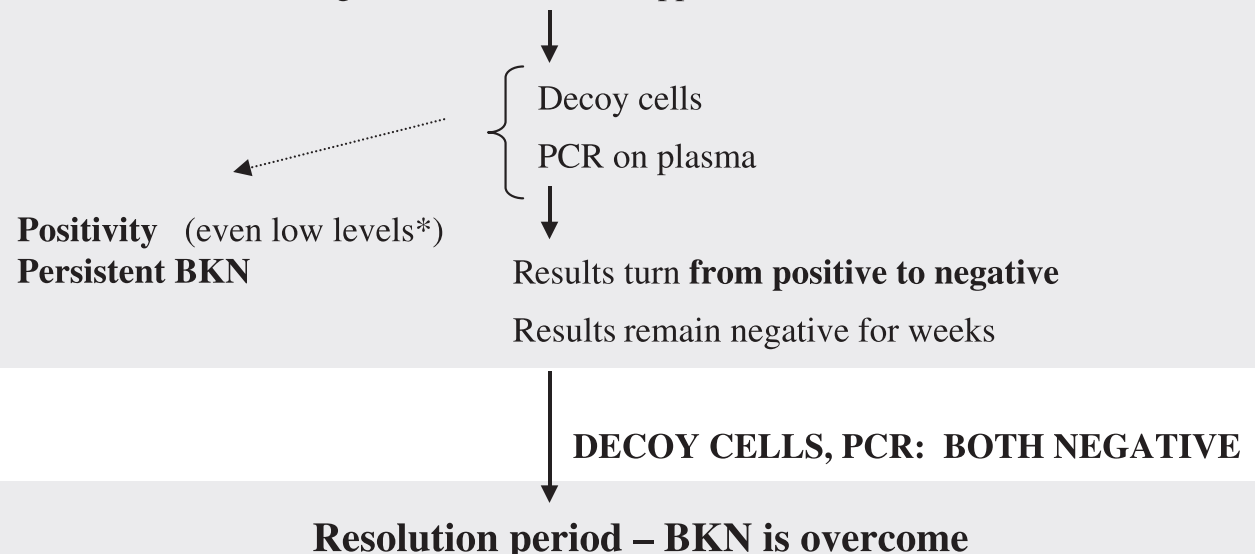

Kidney biopsy for confirmation optional

* Significant PCR threshold levels are not definitively established; plasma load analyses are best suited for patient management

Figure 4 Schematic algorithm of patient screening and monitoring protocols (modified from Ref. [28]). 
mation, i.e. higher numbers of decoy cells do not indicate a higher risk level [28]. As patients developing BKN often turn and remain 'decoy cell positive' months before the initial histologic diagnosis of a viral nephropathy, repeat cytology testing is helpful for proper risk assessment $[13,28,31,41,73]$. Decoy cell positive renal allograft recipients fall into risk level 1; they have to be closely monitored at 4-week intervals using repeat cytology examinations and additional quantitative (plasma) PCR tests (Fig. 4).

\section{Urine electron microscopy}

Negative staining electron microscopy on urine samples to search for free virions is a well established technique;

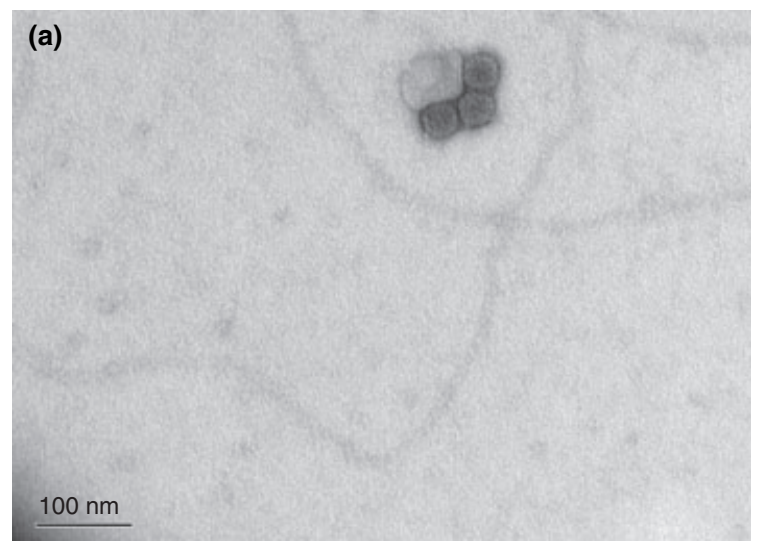

(b)

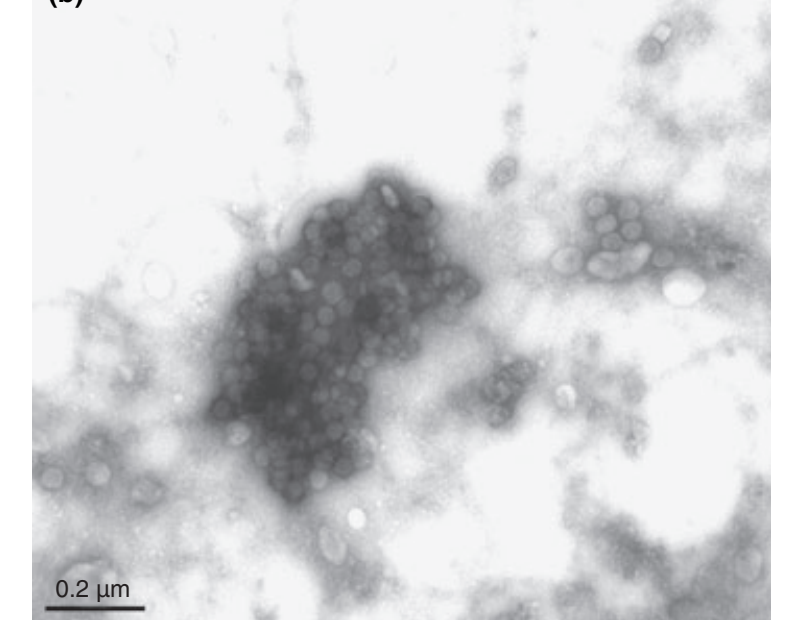

Figure $\mathbf{5} \mathbf{a}, \mathbf{b}$ Negative staining electron microscopy of urine samples. (a) shows typical free virions of approximately 45 nanometers in diameter, consistent with polyomaviruses. The shedding of free viral particles is a sign of viral activation (risk level 1). (b) illustrates a large three-dimensional viral aggregate (a so-called 'Haufen'). The detection of 'Haufen' is in our experience highly sensitive and specific for BKN (risk level 2). Uranyl acetate, $\times 125000$ (a) and $\times 63000$ (b) original magnifications. however, it has only been used sporadically in the setting of BKN $[23,40,94]$ (Fig. $5 \mathrm{a}$ and b). Free virions are generally found in 'decoy positive' kidney transplant recipients with urine BK-virus load levels greater than $1 \times 10^{6}$ copies/ml (measured by PCR) $[40,94]$. The shedding of free viral particles follows a dynamic pattern, closely paralleling the excretion of decoy cells. Patients with detectable free virions fall into risk level 1; they have to be closely monitored at 4 -week intervals using quantitative (plasma) PCR tests. Analyzing negative staining EM results semi-quantitatively [94] and scoring three-dimensional viral cluster formation (i.e. so-called viral 'Haufen'; Fig. 5b) may, in the future, add significant clinical information to more precisely predict $\mathrm{BKN}$.

\section{Quantitative PCR analyses on urine and plasma}

In 2000, Biel et al. introduced the first quantitative realtime PCR assay for the detection of polyomaviruses in the urine [99] that was soon followed by BK-virus-specific tests $[31,92,93,100]$. These quantitative assays have vastly improved patient management. The overall positive predictive value of a 'positive quantitative plasma PCR test' to predict $\mathrm{BKN}$ is $50 \%$ and the negative predictive value is $100 \%$ [31]; plasma viral load levels of greater than $1 \times 10^{4}$ copies/ml have a positive predictive value of greater than $80 \%$. Depending on the viral load levels in the plasma and/or urine, patients can be grouped into risk levels 1 or 2. 'Presumptive BKN, risk level 2' is assumed in a patient with BK-virus loads exceeding $1 \times 10^{4}$ copies $/ \mathrm{ml}$ in the plasma and/or $1 \times 10^{7}$ copies $/ \mathrm{ml}$ in the urine $[30-32,73,93]$. In these patients, an allograft biopsy is indicated to establish a definitive diagnosis. The absence of viremia and/or viruria practically rules out a diagnosis of BKN $[32,93]$.

BK viruria and viremia with varying viral load levels are not uncommon in kidney transplant recipients; they most frequently occur during the first year after grafting as asymptomatic events never leading to viral nephropathy (BK viruria: $35-57 \%$, BK viremia: $7-29 \%$ of patients) [31,101-104]. Approximately $50 \%$ of the viremic episodes are transient, one-time phenomena [101,102]. In some patients, persistent BK viremia can be seen as a prodromal stage of BKN $[28,31,41]$. In daily clinical practice, measurements of plasma or urine BK-virus loads are suited for screening purposes. We and others [105] prefer plasma over urine testing as we feel that the plasma test results are more easily interpretable and critical plasma viral load levels are better defined (also see [94]).

Although quantitative PCR assays of urine and plasma samples are commonly used in the management of renal transplant recipients, results and recommendations have to be interpreted with caution: (i) Some guidelines are 
based only on the analysis of small, select patient populations [31]. (ii) PCR assays are not standardized and protocols vary considerably from laboratory to laboratory. The inter-laboratory variability of test results can exceed $1 \log 10$ (J. Gordon et al., personal communication). (iii) Clinically significant viral load levels remain undetermined. For example, we histologically diagnosed BKN in patients with low plasma load levels $\left(2 \times 10^{3}\right.$ copies $\left./ \mathrm{ml}\right)$, whereas in other patients with high plasma loads $\left(3 \times 10^{4}\right.$ copies/ml) viral nephropathy was never found even in repeat biopsies. (iv) Critical BK-virus 'threshold levels' only apply at the time of initial diagnostic work-up and not during persistent viral nephropathy to monitor for viral clearance (Fig. 4). (v) BK viremia should not be automatically interpreted as 'of kidney origin'. It has also been seen in bone marrow transplant recipients, some of them with clinical signs of hemorrhagic cystitis [106,107]. Thus, viremia can only serve as a general marker of 'BK-virus activation' (Table 1).

During persistent $\mathrm{BKN}$, the response to therapy (e.g. lowering of immunosuppression, changing drug regimens to cyclosporine and azathioprine, therapeutic attempts with low-dose cidofovir or leflunomide) [32,100,105,108110] can be monitored by all of the above-mentioned techniques at 4 -week intervals, i.e. monitoring phase $[28,32,40,41]$. If decoy cells, free virions, and three dimensional viral aggregates (Haufen) disappear from the urine and plasma PCR assays become negative on repeat evaluation, then the histologic resolution of $\mathrm{BKN}$ can be assumed (viral clearance from the kidney; Fig. 4). BK viruria (evaluated by PCR) often persists after viral clearance from the kidney, although at much lower concentrations than seen at the time of initial diagnosis [40,93]. Viral resolution typically takes many months. In most studies, a period of $>12$ weeks of reduced immunosuppression as primary intervention for $\mathrm{BKN}$ has been required to mount an antiviral host response and to significantly reduce viral load levels [111]. We have only seen one exceptional case of a patient with biopsy proven BKN (histologic stage A) who cleared the virus from the graft within 3.5 weeks under low-dose immunosuppression and leflunomide therapy. This case, however, is the exception, not the rule.

The best timing and strategies for the prevention and treatment of BKN are currently undetermined [32,47]. As viral nephropathy seems to be an indicator of intense/ over-immunosuppression [12,26,112] and as outcome depends on an early diagnosis $[28,38,46]$, therapeutic intervention may already be initiated at risk level 2 (Fig. 4) when patients present with signs of significant viral activation but lack histologic proof of BKN ([101], Ginevri et al. reviewed in Ref. [105]). Viremia (but not viruria) is commonly absent in nontransplant patients and may serve as the earliest indicator of 'over-immunosuppression'. Initial reports from one transplant center suggest that early therapy including low-dose immunosuppression at risk level 2 prevents $\mathrm{BKN}$, and does not increase the risk of acute rejection [101]. However, experience is limited and it remains to be determined whether 'significant viremia' (risk level 2) or alternatively histologic proof of BKN (level 3, definitive BKN in early disease stage A) are the best clinical landmarks for therapeutic intervention. '...Prevention of infection whenever possible with prophylactic or preemptive (...) therapy, and prompt diagnosis and aggressive treatment of microbial invasion when prevention fails...' are the ultimate goals [113].

If kidney allografts are lost because of progressive BKN, re-transplantation is a good option. Small case series have provided encouraging results: recurrent BKN was only observed in approximately $12 \%$ of all repeat allografts $[111,114,115]$.

\section{References}

1. Dugan AS, Eash S, Atwood WJ. An N-linked glycoprotein with alpha(2,3)-linked sialic acid is a receptor for BK virus. J Virol 2005; 79: 14442.

2. Low JA, Magnuson B, Tsai B, Imperiale MJ. Identification of gangliosides GD1b and GT1b as receptors for BK virus. $J$ Virol 2006; 80: 1361.

3. Eash S, Querbes W, Atwood WJ. Infection of vero cells by BK virus is dependent on caveolae. J Virol 2004; 78: 11583.

4. Eash S, Atwood WJ. Involvement of cytoskeletal components in BK virus infectious entry. J Virol 2005; 79: 11734.

5. Drachenberg CB, Papadimitriou JC, Wali R, Cubitt CL, Ramos E. BK polyoma virus allograft nephropathy: ultrastructural features from viral cell entry to lysis. Am J Transplant 2003; 3: 1383.

6. Nickeleit V, Singh HK, Gilliland MGF, Thompson D, Romeo C. Latent polyomavirus type BK loads in native kidneys analyzed by TaqMan PCR: what can be learned to better understand BK virus nephropathy? J Am Soc Nephrol 2003; 14: 424A (abstract).

7. Boldorini R, Veggiani C, Barco D, Monga G. Kidney and urinary tract polyomavirus infection and distribution: molecular biology investigation of 10 consecutive autopsies. Arch Pathol Lab Med 2005; 129: 69.

8. Chesters PM, Heritage J, McCance DJ. Persistence of DNA sequences of BK virus and JC virus in normal human tissues and in diseased tissues. J Infect Dis 1983; 147: 676 .

9. Heritage J, Chesters PM, McCane DJ. The persistence of papovavirus BK DNA sequences in normal human renal tissue. J Med Virol 1981; 8: 143. 
10. Polo C, Perez JL, Mielnichuck A, Fedele CG, Niubo J, Tenorio A. Prevalence and patterns of polyomavirus urinary excretion in immunocompetent adults and children. Clin Microbiol Infect 2004; 10: 640.

11. Nickeleit V, Gordon J, Thompson D, Romeo C. Antibody titers and latent polyoma-BK-virus (BKV) loads in the general population: potential donor risk assessment for the development of BK-virus nephropathy (BKN) post transplantation. J Am Soc Nephrol 2004; 15: 524A (abstract).

12. Binet I, Nickeleit V, Hirsch HH, et al. Polyomavirus disease under new immunosuppressive drugs: a cause of renal graft dysfunction and graft loss. Transplantation 1999; 67: 918.

13. Singh HK, Bubendorf L, Mihatsch MJ, Drachenberg CB, Nickeleit V. Urine cytology findings of polyomavirus infections. In: Ahsan N, ed. Polyomaviruses and Human Diseases, 1st edn. New York/Georgetown, TX: Springer Science/Business Media, Landes Bioscience/Eurekah.com, 2006: 201-212.

14. Tani EM, Montenegro MR, Viana de Camargo JL. Urinary bladder washings in autopsies. A cytopathologic study of 63 cases. Acta Cytol 1983; 27: 128.

15. van Gorder MA, Della Pelle P, Henson JW, Sachs DH, Cosimi AB, Colvin RB. Cynomolgus polyoma virus infection: a new member of the polyoma virus family causes interstitial nephritis, ureteritis, and enteritis in immunosuppressed cynomolgus monkeys. Am J Pathol 1999; 154: 1273.

16. Zaragoza C, Li RM, Fahle GA, et al. Squirrel monkeys support replication of BK virus more efficiently than simian virus 40: an animal model for human BK virus infection. J Virol 2005; 79: 1320.

17. Atencio IA, Shadan FF, Zhou XJ, Vaziri ND, Villarreal LP. Adult mouse kidneys become permissive to acute polyomavirus infection and reactivate persistent infections in response to cellular damage and regeneration. J Virol 1993; 67: 1424.

18. Han Lee ED, Kemball CC, Wang J, et al. A mouse model for polyomavirus-associated nephropathy of kidney transplants. Am J Transplant 2006; 6 (5 pt1): 913.

19. Nickeleit V. Animal models of polyomavirus nephropathy: hope and reality. Am J Transplant 2006; 6: 1507.

20. Mackenzie EF, Poulding JM, Harrison PR, Amer B. Human polyoma virus (HPV) - a significant pathogen in renal transplantation. Proc Eur Dial Transplant Assoc 1978; 15: 352.

21. Nickeleit V, Hirsch HH, Binet IF, et al. Polyomavirus infection of renal allograft recipients: from latent infection to manifest disease. J Am Soc Nephrol 1999; 10: 1080.

22. Drachenberg CB, Beskow CO, Cangro CB, et al. Human polyoma virus in renal allograft biopsies: morphological findings and correlation with urine cytology. Hum Pathol 1999; 30: 970.
23. Howell DN, Smith SR, Butterly DW, et al. Diagnosis and management of BK polyomavirus interstitial nephritis in renal transplant recipients. Transplantation 1999; 68: 1279.

24. Pappo O, Demetris AJ, Raikow RB, Randhawa PS. Human polyoma virus infection of renal allografts: histopathologic diagnosis, clinical significance, and literature review. Mod Pathol 1996; 9: 105.

25. Randhawa PS, Finkelstein S, Scantlebury V, et al. Human polyoma virus-associated interstitial nephritis in the allograft kidney. Transplantation 1999; 67: 103.

26. Mengel M, Marwedel M, Radermacher J, et al. Incidence of polyomavirus-nephropathy in renal allografts: influence of modern immunosuppressive drugs. Nephrol Dial Transplant 2003; 18: 1190.

27. Rocha PN, Plumb TJ, Miller SE, Howell DN, Smith SR. Risk factors for BK polyomavirus nephritis in renal allograft recipients. Clin Transplant 2004; 18: 456.

28. Nickeleit V, Steiger J, Mihatsch MJ. BK virus infection after kidney transplantation. Graft 2002; 5 (December supplement): S46.

29. Nickeleit V, Singh HK, Mihatsch MJ. Polyomavirus nephropathy: morphology, pathophysiology, and clinical management. Curr Opin Nephrol Hypertens 2003; 12: 599.

30. Smith JM, McDonald RA, Finn LS, Healey PJ, Davis CL, Limaye AP. Polyomavirus nephropathy in pediatric kidney transplant recipients. Am J Transplant 2004; 4: 2109.

31. Hirsch HH, Knowles W, Dickenmann M, et al. Prospective study of polyomavirus type BK replication and nephropathy in renal-transplant recipients. $N$ Engl J Med 2002; 347: 488.

32. Hirsch HH, Brennan DC, Drachenberg CB, et al. Polyomavirus-associated nephropathy in renal transplantation: interdisciplinary analyses and recommendations. Transplantation 2005; 79: 1277.

33. Awadalla Y, Randhawa P, Ruppert K, Zeevi A, Duquesnoy RJ. HLA mismatching increases the risk of BK virus nephropathy in renal transplant recipients. Am J Transplant 2004; 4: 1691.

34. Sachdeva MS, Nada R, Jha V, Sakhuja V, Joshi K. The high incidence of BK polyoma virus infection among renal transplant recipients in India. Transplantation 2004; 77: 429.

35. Lipshutz GS, Flechner SM, Govani MV, Vincenti F. BK nephropathy in kidney transplant recipients treated with a calcineurin inhibitor-free immunosuppression regimen. Am J Transplant 2004; 4: 2132.

36. Binet I, Nickeleit V, Hirsch HH. Polyomavirus infections in transplant recipients. Curr Opin Org Transplant 2000; 5: 210 .

37. Ramos E, Drachenberg CB, Papadimitriou JC, et al. Clinical course of polyoma virus nephropathy in 67 renal transplant patients. J Am Soc Nephrol 2002; 13: 2145.

38. Buehrig CK, Lager DJ, Stegall MD, et al. Influence of surveillance renal allograft biopsy on diagnosis and prognosis 
of polyomavirus-associated nephropathy. Kidney Int 2003; 64: 665.

39. Ramos E, Drachenberg CB, Portocarrero M, et al. BK virus nephropathy diagnosis and treatment: experience at the University of Maryland renal transplant program. In: Cecka J, Terasaki P, eds. Clinical Transplants. Los Angeles, CA: Immunogenetics Center, 2002: 143-153.

40. Tong CY, Hilton R, MacMahon EM, et al. Monitoring the progress of BK virus associated nephropathy in renal transplant recipients. Nephrol Dial Transplant 2004; 19: 2598.

41. Nickeleit V, Hirsch HH, Zeiler M, et al. BK-virus nephropathy in renal transplants-tubular necrosis, MHC-class II expression and rejection in a puzzling game. Nephrol Dial Transplant 2000; 15: 324.

42. Afzal O, Hussain SA, Bresnahan BA, Zhu Y, Hariharan S. Graft loss associated with polyoma virus nephritis. (abstract). Am J Transplant 2003; 3: A372.

43. Trofe J, Gaber LW, Stratta RJ, et al. Polyomavirus in kidney and kidney-pancreas transplant recipients.

Transpl Infect Dis 2003; 5: 21.

44. Kang YN, Han SM, Park KK, Jeon DS, Kim HC. BK virus infection in renal allograft recipients. Transplant Proc 2003; 35: 275.

45. Mayr M, Nickeleit V, Hirsch HH, Dickenmann M, Mihatsch MJ, Steiger J. Polyomavirus BK nephropathy in a kidney transplant recipient: critical issues of diagnosis and management. Am J Kidney Dis 2001; 38: E13.

46. Drachenberg CB, Papadimitriou JC, Wali R, et al. Improved outcome of polyoma virus allograft nephropathy with early biopsy. Transplant Proc 2004; 36: 758 .

47. Wadei HM, Rule AD, Lewin M, et al. Kidney transplant function and histological clearance of virus following diagnosis of polyomavirus-associated nephropathy (PVAN). Am J Transplant 2006; 6 (5 pt 1): 1025.

48. Baksh FK, Finkelstein SD, Swalsky PA, Stoner GL, Ryschkewitsch CF, Randhawa P. Molecular genotyping of $\mathrm{BK}$ and JC viruses in human polyomavirus-associated interstitial nephritis after renal transplantation. Am J Kidney Dis 2001; 38: 354.

49. Trofe J, Cavallo T, First MR, et al. Polyomavirus in kidney and kidney-pancreas transplantation: a defined protocol for immunosuppression reduction and histologic monitoring. Transplant Proc 2002; 34: 1788.

50. Kazory A, Ducloux D, Chalopin JM, Angonin R, Fontaniere $\mathrm{B}$, Moret $\mathrm{H}$. The first case of JC virus allograft nephropathy. Transplantation 2003; 76: 1653.

51. Milstone A, Vilchez RA, Geiger X, Fogo AB, Butel JS, Dummer S. Polyomavirus simian virus 40 infection associated with nephropathy in a lung-transplant recipient. Transplantation 2004; 77: 1019.

52. Bruno B, Zager RA, Boeckh MJ, et al. Adenovirus nephritis in hematopoietic stem-cell transplantation. Transplantation 2004; 77: 1049.
53. Nada R, Sachdeva MU, Sud K, Jha V, Joshi K. Co-infection by cytomegalovirus and BK polyoma virus in renal allograft, mimicking acute rejection. Nephrol Dial Transplant 2005; 20: 994.

54. Rosen S, Harmon W, Krensky AM, et al. Tubulo-interstitial nephritis associated with polyomavirus (BK type) infection. N Engl J Med 1983; 308: 1192.

55. de Silva LM, Bale P, de Courcy J, Brown D, Knowles W. Renal failure due to BK virus infection in an immunodeficient child. J Med Virol 1995; 45: 192.

56. Haririan A, Ramos ER, Drachenberg CB, Weir MR, Klassen DK. Polyomavirus nephropathy in native kidneys of a solitary pancreas transplant recipient. Transplantation 2002; 73: 1350.

57. Schmid H, Burg M, Kretzler M, Banas B, Grone HJ, Kliem V. BK virus associated nephropathy in native kidneys of a heart allograft recipient. Am J Transplant 2005; 5: 1562.

58. Stracke S, Helmchen U, von Muller L, Bunjes D, Keller F. Polyoma virus-associated interstitial nephritis in a patient with acute myeloic leukaemia and peripheral blood stem cell transplantation. Nephrol Dial Transplant 2003; 18: 2431.

59. Schwarz A, Mengel M, Haller H, Niedermeyer J. Polyoma virus nephropathy in native kidneys after lung transplantation. Am J Transplant 2005; 5: 2582.

60. Limaye AP, Smith KD, Cook L, et al. Polyomavirus nephropathy in native kidneys of non-renal transplant recipients. Am J Transplant 2005; 5: 614.

61. Nickeleit V, Mihatsch MJ. Polyomavirus nephropathy: pathogenesis, morphological and clinical aspects. In: Kreipe HH, ed. Verh Dtsch Ges Pathol, 88. Tagung. Muenchen, Jena: Urban \& Fischer, 2004: 69-84.

62. Petrogiannis-Haliotis T, Sakoulas G, Kirby J, et al. BKrelated polyomavirus vasculopathy in a renal-transplant recipient. N Engl J Med 2001; 345: 1250.

63. Funk GA, Steiger J, Hirsch HH. Rapid dynamics of polyomavirus type BK in renal transplant recipients. I Infect Dis 2006; 193: 80.

64. Coleman DV, Mackenzie EF, Gardner SD, Poulding JM, Amer B, Russell WJ. Human polyomavirus (BK) infection and ureteric stenosis in renal allograft recipients. J Clin Pathol 1978; 31: 338.

65. Karam G, Maillet F, Parant S, Soulillou JP, Giral-Classe M. Ureteral necrosis after kidney transplantation: risk factors and impact on graft and patient survival. Transplantation 2004; 78: 725.

66. McCabe MT, Low JA, Imperiale MJ, Day ML. Human polyomavirus BKV transcriptionally activates DNA methyltransferase 1 through the $\mathrm{pRb} / \mathrm{E} 2 \mathrm{~F}$ pathway. Oncogene 2006; 25: 2727.

67. Drachenberg CB, Hirsch HH, Ramos E, Papadimitriou JC. Polyomavirus disease in renal transplantation: review of pathological findings and diagnostic methods. Hum Pathol 2005; 36: 1245. 
68. Koss LG. Chapter 22: the lower urinary tract in the absence of cancer. In: Koss LG, Melamed MR, eds. Koss' Diagnostic Cytology and its Histopathologic Basis, 5th edn. Philadelphia, PA: Lippincott Wiliams and Wilkins, 2006: 738-776.

69. Herawi M, Parwani AV, Chan T, Ali SZ, Epstein JI. Polyoma virus-associated cellular changes in the urine and bladder biopsy samples: a cytohistologic correlation. Am J Surg Pathol 2006; 30: 345.

70. Bracamonte ER, Furmanczyk PS, Smith KD, Nicosia RF, Alpers CE, Kowalewska J. Tubular basement membrane immune deposits associated with polyoma virus nephropathy in renal allografts. Lab Invest 2006; 86 (Suppl. 1): 259A (abstract).

71. Nickeleit V, Mihatsch MJ. Polyomavirus allograft nephropathy and concurrent acute rejection: a diagnostic and therapeutic challenge. Am J Transplant 2004; 4: 838.

72. Nickeleit V, Zeiler M, Gudat F, Thiel G, Mihatsch MJ. Detection of the complement degradation product C4d in renal allografts: diagnostic and therapeutic implications. J Am Soc Nephrol 2002; 13: 242.

73. Drachenberg CB, Papadimitriou JC, Hirsch HH, et al. Histological patterns of polyomavirus nephropathy: correlation with graft outcome and viral load. Am J Transplant 2004; 4: 2082.

74. Nickeleit V, Steiger J, Mihatsch MJ. Re: noninvasive diagnosis of BK virus nephritis by measurement of messenger RNA for BK virus VP1. Transplantation 2003; 75: 2160 (letter).

75. Boldorini R, Brustia M, Veggiani C, Barco D, Andorno S, Monga G. Periodic assessment of urine and serum by cytology and molecular biology as a diagnostic tool for BK virus nephropathy in renal transplant patients. Acta Cytol 2005; 49: 235.

76. Singh HK, Nickeleit V. Kidney disease caused by viral infections. Curr Diag Pathol 2004; 10: 11.

77. Asim M, Chong-Lopez A, Nickeleit V. Adenovirus infection of a renal allograft. Am J Kidney Dis 2003; 41: 696.

78. Parkin RK, Boeckh MJ, Erard V, Huang ML, Myerson D. Specific delineation of BK polyomavirus in kidney tissue with a digoxigenin-labeled DNA probe. Mol Cell Probes 2005; 19: 87.

79. Randhawa PS, Vats A, Zygmunt D, et al. Quantitation of viral DNA in renal allograft tissue from patients with BK virus nephropathy. Transplantation 2002; 74: 485.

80. Schmid H, Nitschko H, Gerth J, et al. Polyomavirus DNA and RNA detection in renal allograft biopsies: results from a European multicenter study. Transplantation 2005; 80: 600.

81. Randhawa P, Shapiro R, Vats A. Quantitation of DNA of polyomaviruses BK and JC in human kidneys. J Infect Dis 2005; 192: 504.

82. Drachenberg RC, Drachenberg CB, Papadimitriou JC, et al. Morphological spectrum of polyoma virus disease in renal allografts: diagnostic accuracy of urine cytology. Am J Transplant 2001; 1: 373.
83. Chen Y, Trofe J, Gordon J, et al. Interplay of cellular and humoral immune responses against BK virus in kidney transplant recipients with polyomavirus nephropathy. J Virol 2006; 80: 3495.

84. Celik B, Shapiro R, Vats A, Randhawa PS. Polyomavirus allograft nephropathy: sequential assessment of histologic viral load, tubulitis, and graft function following changes in immunosuppression. Am J Transplant 2003; 3: 1378.

85. Jeong HJ, Hong SW, Sung SH, et al. Polyomavirus nephropathy in renal transplantation: a clinico-pathological study. Transpl Int 2003; 16: 671.

86. Ahuja M, Cohen EP, Dayer AM, et al. Polyoma virus infection after renal transplantation. Use of immunostaining as a guide to diagnosis. Transplantation 2001; 71: 896.

87. Mannon RB, Hoffmann SC, Kampen RL, et al. Molecular evaluation of BK polyomavirus nephropathy. Am J Transplant 2005; 5: 2883.

88. Farasati NA, Shapiro R, Vats A, Randhawa P. Effect of leflunomide and cidofovir on replication of BK virus in an in vitro culture system. Transplantation 2005; 79: 116.

89. Nickeleit V, Klimkait T, Binet IF, et al. Testing for polyomavirus type BK DNA in plasma to identify renal allograft recipients with viral nephropathy. $N$ Engl J Med 2000; 342: 1309.

90. Kiberd BA. Screening to prevent polyoma virus nephropathy: a medical decision analysis. Am J Transplant 2005; 5: 2410.

91. Ding R, Medeiros M, Dadhania D, et al. Noninvasive diagnosis of BK virus nephritis by measurement of messenger RNA for BK virus VP1 in urine. Transplantation 2002; 74: 987.

92. Limaye AP, Jerome KR, Kuhr CS, et al. Quantitation of $\mathrm{BK}$ virus load in serum for the diagnosis of BK virusassociated nephropathy in renal transplant recipients. J Infect Dis 2001; 183: 1669.

93. Randhawa P, Ho A, Shapiro R, et al. Correlates of quantitative measurement of BK polyomavirus (BKV) DNA with clinical course of BKV infection in renal transplant patients. J Clin Microbiol 2004; 42: 1176.

94. Singh HK, Madden V, Shen YJ, Thompson D, Nickeleit $\mathrm{V}$. Negative staining electron microscopy of urine for the detection of polyomavirus infections. Ultrastruct Pathol 2006 (in press).

95. Gai M, Lanfranco G, Segoloni GP. Decoy cells in urine. Transplant Proc 2005; 37: 4309.

96. Fogazzi GB, Garigali G. The clinical art and science of urine microscopy. Curr Opin Nephrol Hypertens 2003; 12: 625.

97. Fogazzi GB, Cantu M, Saglimbeni L. 'Decoy cells' in the urine due to polyomavirus BK infection: easily seen by phase-contrast microscopy. Nephrol Dial Transplant 2001; 16: 1496.

98. Itoh S, Irie K, Nakamura Y, Ohta Y, Haratake A, Morimatsu M. Cytologic and genetic study of polyomavirus-infected or polyomavirus-activated cells in human urine. Arch Pathol Lab Med 1998; 122: 333. 
99. Biel SS, Held TK, Landt O, et al. Rapid quantification and differentiation of human polyomavirus DNA in undiluted urine from patients after bone marrow transplantation. J Clin Microbiol 2000; 38: 3689.

100. Vats A, Shapiro R, Singh Randhawa P, et al. Quantitative viral load monitoring and cidofovir therapy for the management of $\mathrm{BK}$ virus-associated nephropathy in children and adults. Transplantation 2003; 75: 105.

101. Brennan DC, Agha I, Bohl DL, et al. Incidence of BK with tacrolimus versus cyclosporine and impact of preemptive immunosuppression reduction. Am J Transplant 2005; 5: 582.

102. Razonable RR, Brown RA, Humar A, Covington E, Alecock E, Paya CV. A longitudinal molecular surveillance study of human polyomavirus viremia in heart, kidney, liver, and pancreas transplant patients. J Infect Dis 2005; 192: 1349.

103. Bressollette-Bodin C, Coste-Burel M, Hourmant M, Sebille V, Andre-Garnier E, Imbert-Marcille BM. A prospective longitudinal study of BK virus infection in 104 renal transplant recipients. Am J Transplant 2005; 5: 1926.

104. Randhawa P, Uhrmacher J, Pasculle W, et al. A comparative study of BK and JC virus infections in organ transplant recipients. J Med Virol 2005; 77: 238.

105. Trofe J, Hirsch HH, Ramos E. Polyomavirus associated nephropathy: update of clinical management in kidney transplant patients. Transpl Infect Dis 2006; 8: 76.

106. Erard V, Kim HW, Corey L, et al. BK DNA viral load in plasma: evidence for an association with hemorrhagic cystitis in allogeneic hematopoietic cell transplant recipients. Blood 2005; 106: 1130.
107. Erard V, Storer B, Corey L, et al. BK virus infection in hematopoietic stem cell transplant recipients: frequency, risk factors, and association with postengraftment hemorrhagic cystitis. Clin Infect Dis 2004; 39: 1861.

108. Williams JW, Javaid B, Kadambi PV, et al. Leflunomide for polyomavirus type BK nephropathy. $N$ Engl J Med 2005; 352: 1157.

109. Kuypers DR, Vandooren AK, Lerut E, et al. Adjuvant low-dose cidofovir therapy for BK polyomavirus interstitial nephritis in renal transplant recipients. Am J Transplant 2005; 5: 1997.

110. Josephson MA, Gillen D, Javaid B, et al. Treatment of renal allograft polyoma BK virus infection with leflunomide. Transplantation 2006; 81: 704.

111. Hirsch HH, Ramos E. Retransplantation after polyomavirus-associated nephropathy: just do it? Am J Transplant 2006; 6: 7.

112. Lerut E, Kuypers DR, Van Damme B. Polyomavirus interstitial nephritis and concurrent post-transplant lymphoma in a renal allograft: coincidence or more? Transpl Int 2005; 18: 1304.

113. Marty FM, Rubin RH. The prevention of infection post-transplant: the role of prophylaxis, preemptive and empiric therapy. Transpl Int 2006; 19: 2.

114. Ramos E, Vincenti F, Lu WX, et al. Retransplantation in patients with graft loss caused by polyoma virus nephropathy. Transplantation 2004; 77: 131.

115. Womer K, Meier-Krieschke HU, Patton P, et al. Preemptive retransplantation for BK virus nephropathy: successful outcome despite active viremia. Am J Transplant 2006; 6: 209. 